\title{
ПРОБЛЕМИ РОЗСЛДУВАННЯ ПІДКУПУ ВИБОРЦЯ, УЧАСНИКА РЕФЕРЕНДУМУ
}

\author{
ГРИГОРОВА Свгенія Володимирівна - здобувач кафедри досудового \\ розслідування ННІ № 1 Національної академії внутрішніх справ \\ DOI:10.32782/LAW.2019.3.21 \\ УДК 343. 98
}

\begin{abstract}
У статті, на основі аналізу практики розслідування, а також наукових та інших інбормаційних джерел здійснено аналіз найбільш суттевих ускладнень, що виникають під иас розслідування підкупу вибория, учасника реберендуму. Акцентовано, що серед злочинів, пов'язаних з порушенням виборчих прав громадян, підкуп вибория, учасника референдуму $\epsilon$ одним найбільш небезпечних злочинних проявів, які можуть негативно вплинути на результати народного волевиявлення.
\end{abstract}

Наголошено на необхідності застосування слідчими спеціальних знань та положень нормативно-правових актів, що урегульовують виборчий прощес в Україні, у тому числі знанні та умінні працювати з відповідними специфічними документальними джерелами інбормаиї.

Виявлено низъкий рівень методичного забезпечення розслідування таких злочинів, а також часто недостатній досвід слідиих у таких провадженнях, що призводить до виникнення тактичних помилок.

Підкреслено потребу у налагодженні ефективної взаємодї з широким колом суб'єктів - учасників виборчих перегонів, а також залученні до процесу розслідування спеціалістів для отримання квалібікованої допомоги.

Встановлено, що зважаючи на переважно латентний характер досліджуваних злочинів, що розглядаються, пошук та формування доказової бази у таких провадженнях є ускладненим, особливо в умовах процесуальних обмежень щодо можливості проведення деяких слідчих (розиукових) дій, які випливають з положень иинної кримінальної норми.

Констатовано, що негативний вплив на ефективність виявлення та розслідування злочинів, щьо досліджуються, здійснюе толерантне ставлення значної частини громадян до дій, що містять ознаки одержання неправомірної вигоди під час виборчих перегонів.

Ключові слова: проблеми розслідування, підкуn, виборчий прочес, неправомірна вигода.

\section{Постановка проблеми}

Виборче право є одним 3 найважливіших політичних прав людини та громадянина, оскільки результатом його реалізації є формування органів законодавчої влади та місцевого самоврядування. Під час виборів формується політична еліта суспільства, відбувається відбір політичних лідерів, які, у свою чергу, здійснюючи керівні функції, визначатимуть стратегічні вектори зовнішньої та внутрішньої політики держави у цілому.

Інтенсифікація виборчих процесів останнім часом, $з$ одного боку, демонструє демократичний вектор розвитку нашої держави, але 3 іншого - викриває проблеми, що підтверджують недосконалість існуючої виборчої системи. Примітно, що однією 3 масових проблем виборчого процесу стала реалізація в різних регіонах нашої країни різноманітних технологій, пов'язаних 3 підкупом виборців. Так, за свідченнями громадянської мережі «Опора», враховуючи непоодиноку спрямованість значної 
частини кандидатів щодо матеріального мотивування виборців, найбільша кількість досудових розслідувань щодо фактів підкупу виборців (41\% від загальної кількості проваджень, що відкриті у зв’язку з порушенням виборчих прав) є прогнозованою [1, с. 9]. Водночас, якщо оцінювати наслідки впливу на результати голосування виборців різних типів порушень, то підкуп виборців, без перебільшення, належить до найбільш серйозних із них.

\section{Аналіз останніх досліджень}

Враховуючи безумовну актуальність означеної проблеми, вона неодноразово ставала предметом вивчення у межах наукових досліджень різного спрямування. Так, окремі питання протидії злочинам та іншим правопорушенням у сфері реалізації законодавства про вибори у контексті їх кримінально-правової кваліфікації, особливостей розслідування, кримінологічної характеристики та профілактики досліджували Ю. О. Андрейко, А. В. Гудзь, В. М. Колесниченко, А. М. Колодій, В. В. Кострицький, С. В. Красноголовець, О. В. Кубарєва, О. В. Аавринович, С. Я. Аихова, Т. П. Матюшкова, $\lambda$. П. Медіна, М. І. Мельник, С. А. Мозоль, М. О. Мягков, М. А. Ставнійчук, Ю. М. Тодика, М. І. Хавронюк та ін. Крім того, численні публікації з означеної тематики часто трапляються у засобах масової інформації, втім мають здебільшого публіцистичний характер.

Для протидії зазначеним негативним тенденціям у нашій державі здійснено комплекс заходів різного спрямування. Йдеться, насамперед, про створення на законодавчому рівні відповідної міжнародним стандартам системи гарантування конституційних виборчих прав громадян України, а також забезпечення активної участі у виборчому процесі як міжнародних спостерігачів, так і представників громадськості. Втім, вкрай важливим інструментом протидії зазначеним порушенням є об'єктивне, повне та ефективне розслідування кримінальних проваджень у подібних злочинах та притягнення до відповідальності насамперед організаторів схем підкупу або осіб-замовників так званих «ко- рупційних пірамід», а не лише безпосередніх виконавців злочинних дій.

Як свідчить аналіз практики, розслідування злочинів, передбачених ст. 160 КК України («Підкуп виборця, учасника референдуму»), характеризується цілою низкою ускладнень, що зумовлені різними чинниками. Відтак, метою статті $є$ виявлення та аналіз проблемних аспектів, що виникають під час розслідування означених злочинів.

\section{Виклад основного матеріалу}

Найбільш очевидною особливістю процесу розслідування підкупу виборця, учасника референдуму, є те, що, зважаючи на банкетний характер ст. 160 КК України, процес доказування на початковому етапі розслідування таких злочинів потребує застосування слідчим спеціальних знань щодо організації та проведення виборчого процесу. Відтак, слідчі повинні бути обізнані у питаннях законодавчого регулювання виборів, працювати з різного роду виборчими документами (як важливим джерелом доказової інформації), налагодити взаємодію 3 іншими правоохоронними органами, судами та громадськими організаціями (членами виборчих комісій, офіційними спостерігачами, представниками політичних партій, виборчих штабів і блоків та іншими учасниками виборчого процесу), а також, за необхідності, звертатися по допомогу до відповідних фахівців. Крім того, ускладнення часто виникають і у зв'язку 3 необхідністю встановлення причетності до злочину службових осіб органів влади та місцевого самоврядування. У цьому аспекті доцільно також наголосити на необхідності урахування слідчими можливої протидії 3 боку зацікавлених осіб, а також їхнього соціального становища, посадового чи(i) політичного статусу.

По-друге, оскільки ст. 160 була внесена до Кримінального кодексу України лише у 2014 році, методичне забезпечення процесу розслідування таких злочинів, як і досвід здійснення подібних проваджень працівниками правоохоронних органів часто виявляються недостатніми. Зважаючи на зазначене, слідчі часто припускаються помилок як під час розслідування злочинів, 


\section{Кримінальне право, кримінальний процес та криміналістика}

пов'язаних $з$ порушенням виборчого законодавства у цілому, так і підкупу виборців, зокрема. За результатами вивчення практики, найбільш типовими недоліками у цьому сенсі 6 :

- незнання слідчими та керівниками слідчих підрозділів положень та норм спеціальних статей Кримінального кодексу України щодо злочинів, пов'язаних 3 порушеннями виборчих прав громадян, а також виборчих законодавчих актів. Звідси, як результат - невірна кваліфікація злочинів (зокрема щодо розмежування суміжних складів злочинів, пов'язаних з порушенням виборчого законодавства);

відсутність у більшості кримінальних проваджень планування слідчих (розшукових) дій, і як наслідок - непроведення таких невідкладних першочергових слідчих дій як детальні допити заявників, свідків на місці події (у тому числі їх встановлення); отримання аудіо-, відеозаписів від представників 3МІ, офіційних спостерігачів; огляд території, приміщень, наметів та вилучення відповідних предметів (агітаційні матеріали, продуктові набори, т.з. соціальні угоди, грошові кошти, договори тощо); особисті огляди осіб, які вчиняли протиправні дії. Не здійснюється фотографування та відеофіксація місця події;

- нездійснення слідчої діяльності, спрямованої на формування доказової бази для притягнення до кримінальної відповідальності осіб-організаторів масових підкупів виборців. Зазвичай, за такими злочинами до суду направляються лише рядові виконавці, подальше ж розслідування для встановлення організаторів та замовників злочину не проводиться;

слідчими майже не застосовуються положення ч. 1 ст. 160 КК України щодо притягнення до кримінальної відповідальності виборця за отримання ним неправомірної вигоди [2, с. 3, 4].

Зважаючи на нагальну потребу практики, Головним слідчим управлінням Національної поліції України були підготовлені методичні рекомендації у вигляді алгоритмів першочергових слідчих (розшукових) дій під час досудового розслідування кримінальних правопорушень, пов'язаних 3 порушенням виборчого законодавства при проведенні чергових виборів Президента України 31 березня 2019 року [2] та позачергових виборів до Верховної Ради України 21 липня 2019 року [3]. Проте зазначені документи, практично дублюючи один одного, не охоплюють усіх проблемних аспектів, що виникають під час здійснення розслідувань у таких провадженнях та мають здебільшого інформативний характер щодо особливостей законодавчого закріплення кримінальної відповідальності за виборчі злочини у цілому, а також визначають загальні напрямки здійснення першочергових слідчих (розшукових) дій.

По-третє, злочини, передбачені ст. 160 КК України, характеризуються латентністю перебігу, а відтак пошук та формування доказової бази у таких провадженнях 6 доволі ускладненим. Так, організація схем підкупу, іхнє фінансування, пошук посередників відбуваються приховано, тобто злочин переходить у публічну площину лише на стадії безпосередньої передачі неправомірної вигоди. Отже, повідомлення про такі злочинні дії надходять до правоохоронних органів зазвичай не на момент їх вчинення, а через деякий час після того, як подія злочину вже відбулася. За таких умов основним джерелом доказів можуть бути або показання свідків, або результати негласних слідчих (розшукових) дій. А оскільки діяння 3 підкупу виборця шляхом пропозиції, обіцянки або надання неправомірної вигоди належать до середнього ступеня тяжкості, під час їх розслідування можливе проведення лише таких негласних слідчих (розшукових) дій, як аудіо-, відеоконтроль особи (ст. 260 КПК України) та зняття інформації з транспортних телекомунікаційних мереж (ст. 263 КПК України) [4, с. 205].

У цьому сенсі варто звернути увагу на ще один аспект. Часто трапляється, що суб'єкти виборчого процесу повідомляють правоохоронців про злочини вже після встановлення результатів голосування та з'ясування мінімального відриву у голосах між кандидатами. Реагування на ці заяви, які, як правило, не підкріплюються документальними джерелами 3 дільничних чи територіальних виборчих комісій, вибор- 
чих дільниць, пов'язане із необхідністю невідкладно проводити такі слідчі (розшукові) дії, як огляд місця події, обшуки, що вже не є результативними. Більше того, непоодинокими є випадки, коли заяви про вчинення виборчих злочинів виступають елементом політичної боротьби з конкурентами по виборчій кампанії, а іноді лише для оголошення відповідного факту в засобах масової інформації. Як стверджуєТ. П. Матюшкова, це значно збільшує загальну кількість заяв і навантаження на слідчих. Водночас таким діям важко запобігти, оскільки кримінальна відповідальність наступає лише за завідомо неправдиве повідомлення про злочин, тоді як завідому неправдивість такого повідомлення фактично неможливо довести [5, с. 125].

Проте навіть у випадку фіксації порушень норм виборчого законодавства під час їхньої безпосередньої реалізації, слідчі можуть лише спонукати підозрюваних добровільно пред'явити предмети та документи, зокрема виборчі бюлетені чи бланки протоколів, печатку виборчої комісії, телефон, яким здійснено фотофіксацію виборчого бюлетеня, вчинення ж будь-яких слідчих дій (допиту, огляду, вилучення речей і документів) можливе лише після внесення відомостей про злочин у Сдиний реєстр досудових розслідувань [1, с. 12-14].

Для проведення огляду слідчий за погодженням 3 прокурором або прокурор звертається до слідчого судді з відповідним клопотанням. Клопотання про обшук розглядається у суді в день його надходження за участю слідчого або прокурора. Відтак, необхідність здійснення таких дій для вилучення речей та документів (виборчих бюлетенів, телефону, бланків протоколів виборчої комісії) на місці вчинення злочину проти виборчих прав громадян унеможливлює невідкладне документування доказової бази.

Крім того, оскільки санкція ч. 1 ст. 160 КК України (прийняття пропозиції, обіцянки або одержання виборцем, неправомірної вигоди за вчинення чи невчинення будь-яких дій, пов'язаних 3 безпосередньою реалізацією ним свого виборчого права або права голосу) не передбачає позбав- лення волі, представниками Національної поліції не може бути застосовано затримання порушника на місці без ухвали слідчого судді (ст. 208 КПК України). Водночас саме даний вид підкупу найчастіше вчиняється безпосередньо на виборчій дільниці, в день голосування або в публічних місцях та може бути зафіксований спостерігачами.

Для виправлення цієї ситуації громадянською мережею «Опора» спільно 3 Мiністерством внутрішніх справ України та Національною поліцією України був розроблений проект закону «Про внесення змін до деяких законодавчих актів України щодо посилення відповідальності за порушення виборчого законодавства» № 8270 . Зокрема, законопроектом посилюється кримінальна відповідальність за дії, передбачені у тому числі ст. 160 КК України: пропонується ввести санкцію у вигляді позбавлення волі строком до 2 років за отримання виборцем неправомірної вигоди, пов'язаною 3 реалізацією активного або пасивного виборчого права (ч. 1 ст. 160 КК України). Крім того, пропонується посилення відповідальності шляхом збільшення санкції у вигляді позбавлення волі до 6 років у ч.ч. 2 та 3 ст. 160 КК України. Як зазначають автори законопроекту, крім суто профілактичної ролі, дані зміни спрямовані на отримання правових підстав для затримання правопорушника та проведення відповідних процесуальних заходів правоохоронними органами. Крім зазначеного, проектом передбачається звільнення від кримінальної відповідальності осіб (крім організаторів підкупу), які добровільно повідомили правоохоронні органи про вчинення злочинів щодо підкупу виборців та сприяли розслідуванню. Ця новація мотивує сприяти правоохоронцям громадян, яких під час виборів намагатимуться залучити до незаконної діяльності.

3 метою запобігання висування так званих «технічних кандидатів» чи кандидатівдвійників законопроектом криміналізуються дії, спрямовані на підкуп кандидата, а також встановлюється кримінальна відповідальність за здійснення передвиборної агітації, яка супроводжується наданням неправомірної вигоди виборцям (чинний 


\section{Кримінальне право, кримінальний процес та криміналістика}

Кримінальний кодекс передбачає таку відповідальність за надання неправомірної вигоди лише юридичним особам) [6].

У контексті досліджуваної проблеми вважаємо за необхідне звернути увагу на ще один аспект, який, без перебільшення, має суттєвий негативний вплив на ефективність розслідування проваджень, що розглядаються. Йдеться про те, що значна кількість громадян толерантно ставиться до отримання неправомірної вигоди від кандидатів під час виборчих перегонів. Так, Коломієць Ю. М. та Гудзь $\mathcal{\lambda}$. В., проаналізувавши основні правопорушення, вчинені під час виборчих кампаній, дійшли висновку, що однією з основних причин їх скоєння став високий ступінь психологічної готовності значної кількості громадян до цих порушень. Проведений авторами аналіз кількості закритих кримінальних проваджень показав, що більшість порушників виборчого законодавства впевнена у тому, що за вчинене не доведеться відповідати [7]. Дані висновки цілком підтверджуються результатами соціологічних досліджень, проведених і щодо ставлення до підкупу виборців. Зокрема, за результатами опитування, проведеного Соціологічною групою «Рейтинг» у рамках проекту «Портрети регіонів» $15 \%$ респондентів позитивно ставляться до ситуації, коли під час виборів в Україні деякі політики матеріально допомагають виборцям, ще 23 \% займають нейтральну позицію щодо цього питання [8]. При цьому варто наголосити, що, зважаючи на те, що такі дії $е$ кримінально караними, значна частина респондентів могли приховати свою справжню думку, і реальна частка потенційно готових до підкупу осіб могла бути ще більшою.

Зважаючи на вищезазначене, особи вкрай рідко звертаються до правоохоронних органів з відповідними повідомленнями та сприяють проведенню розслідувань таких проваджень, що, у свою чергу, значно знижує позитивну динаміку протидії таким злочинам.

\section{Висновки}

Очевидно, що виявлені проблемні аспекти не вичерпують усіх ускладнень, що можуть виникати під час розслідування підкупу виборця, учасника референдуму. У межах статті нами були виявлені наступні, як нам видається, найбільш суттєві з них:

необхідність застосування слідчим спеціальних знань та положень нормативно-правових актів, що урегульовують організацію виборчого процесу в Україні;

низький рівень методичного забезпечення розслідування таких злочинів, а також часто недостатній досвід здійснення подібних проваджень у слідчих;

- потреба у налагодженні ефективної взаємодії з іншими правоохоронними органами, судами, громадськими організаціями та учасниками виборчих перегонів, а також залученні до процесу розслідування спеціалістів для отримання кваліфікованої допомоги;

- здебільшого латентний характер злочинів, що розглядаються, ускладнюе пошук та формування доказової бази у таких провадженнях, особливо зважаючи на процесуальні обмеження щодо можливості проведення деяких слідчих (розшукових) дій, які у тому числі випливають 3 положень чинної кримінальної норми;

толерантне ставлення значної частини громадян до одержання неправомірної вигоди від кандидатів під час виборчих перегонів, а відтак - небажання співпрацювати з правоохоронними органами у напрямку ефективного виявлення та розслідування злочинів, що досліджуються.

\section{Література}

1. Розслідування злочинів проти виборчих прав на чергових місцевих виборах 2015 року: підсумковий звіт. Громадянська мережа ОПОРА. URL: https:/opora. lviv.ua > wp-content > uploads > 2018/06 > Rozsliduvannya-zl..

2. Алгоритм першочергових слідчих (розшукових) дій під час досудового розслідування кримінальних правопорушень, пов'язаних 3 порушенням виборчого законодавства при проведенні чергових виборів Президента України 31 березня 2019 року, та особливості їх кваліфікації. Київ: Головне слідче управління Національної поліції України, 2019. 44 с. 
3. Алгоритм першочергових слідчих (розшукових) дій під час досудового розслідування кримінальних правопорушень, пов'язаних $з$ порушенням виборчого законодавства при проведенні позачергових виборів до Верховної Ради України 21 липня 2019 року, та особливості їх кваліфікації. Київ: Головне слідче управління Національної поліції України, 2019. 43 с.

4. Андрейко Ю. О. Проведення слідчих (розшукових) дій під час розслідування одержання неправомірної вигоди в кримінальних провадженнях про підкуп виборців. Прикарпатський юридичний вісник.Випуск 1(26), 2019. С. 202-207.

5. Матюшкова Т. П. Деякі проблемні аспекти розслідування злочинів проти виборчих прав громадян. Актуальні питання розслідування та тендениї розвитку криміналістичної методики: матеріали всеукр. наук.практ. конф. (м. Харків, 21 листоп. 2018 р.). Харків, 2018. С. 124-126.

6. Висновок Комітету Верховної Ради України з питань законодавчого забезпечення правоохоронної діяльності щодо проекту Закону про внесення змін до деяких законодавчих актів України щодо посилення відповідальності за порушення виборчого законодавства № 8270 . URL: http://w1.cl.rada.gov.ua/pls/zweb2/ webproc4_1?pf3511=63864.

7. Коломієць Ю. М., Гудзь А. В. Правопорушення на виборах в Україні та шляхи їх подолання. East European Scientific Journal. 2019. № 6(46). Вип. 8. С. 51-54.

8. Більшість українців проти підкупу виборців. URL: https://www.rbc.ua/ukr/ news/ukraintsy-rasskazali-svoem-otnosheniipodkupu-1545841324.html.
In the article, on the basis of analysis of practice of investigation, as well as scientific and other information sources, the analysis of the most significant complications that arise during the investigation of bribery of a voter, a participant of a referendum. It is emphasized that among the crimes related to violation of electoral rights of citizens, bribery of a voter, a participant of a referendum is one of the most dangerous criminal manifestations which can negatively affect the results of popular will.

It is emphasized that investigators need to use special knowledge and provisions of the legal acts that regulate the election process in Ukraine, including knowledge and ability to work with relevant specific documentary sources of information.

A low level of methodological support for the investigation of such crimes has been identified, as well as often insufficient experience of investigators, which leads to tactical errors and generally negatively affects the effectiveness of the investigation.

The need for effective engagement with a wide range of constituents is emphasized, as well as the involvement of experts in the investigation process for qualified assistance.

It is established that, given the predominantly latent nature of the crimes under investigation, the search and formation of an evidence base in such proceedings is difficult, especially in the context of procedural restrictions on the possibility of certain investigative (investigative) actions arising from the provisions of the applicable criminal law.

It is stated that the negative impact on the efficiency of detection and investigation of investigated crimes tolerates the attitude of a considerable part of the citizens to the actions containing the signs of receiving undue benefits during the election race.

Keywords: investigation problems, bribery, electoral process, unlawful gain. 